\title{
Lateral Hypothalamus Is Required for Context-Induced Reinstatement of Extinguished Reward Seeking
}

\author{
Nathan J. Marchant, Adam S. Hamlin, and Gavan P. McNally \\ School of Psychology, The University of New South Wales, Sydney, 2052, Australia
}

We studied the role of lateral hypothalamus (LH) in context-induced reinstatement (renewal) of reward seeking. Rats were trained to respond for $4 \%(\mathrm{v} / \mathrm{v})$ alcoholic beer or $10 \%(\mathrm{w} / \mathrm{v})$ sucrose reward in one context (Context $\mathrm{A})$ before extinction training in a second context (Context $B)$. On test, rats were returned to the training context, $A(A B A)$, or the extinction context, $B(A B B)$. Return to the training context (ABA) produced robust reinstatement. Reversible inactivation of LH via baclofen/muscimol infusion prevented context-induced reinstatement of beer and sucrose seeking. This prevention was specific to bilateral infusions into LH. We then used the retrograde neuronal tracer cholera toxin $b$ subunit $(\mathrm{CTb})$ combined with detection of the c-Fos protein to identify activated afferents to LH during contextinduced reinstatement of beer seeking. Double labeling for c-Fos and CTb revealed a significant recruitment of LH-projecting neurons in nucleus accumbens shell (AcbSh) during reinstatement. These afferents could be classified into two anatomically and functionally distinct groups. First, afferents in the ventral AcbSh projecting to $\mathrm{LH}$ were activated during reinstatement. Second, afferents in the dorsomedial AcbSh projecting to $\mathrm{LH}$ were activated during test in the extinction context. These recruitments were specific to an AcbSh-LH pathway because they were not observed following CTb injection into the immediately adjacent perifornical hypothalamus. These results show that LH is critical for context-induced reinstatement of reward seeking and that parallel striatal-hypothalamic pathways are recruited following return to the training versus extinction contexts.

Key words: accumbens shell; renewal; tracing; c-Fos; relapse; addiction

\section{Introduction}

The contexts where drug self-administration is extinguished exert profound control over drug seeking. Crombag and Shaham (2002) used a renewal design (Bouton and Bolles, 1979) and reported that rats trained to self-administer a heroin-cocaine mixture in one context, context A, and then extinguished in a second, different context, context $\mathrm{B}$, showed a pronounced reinstatement of extinguished drug seeking when tested in context A. This context-induced reinstatement or renewal of extinguished drug seeking has since been reported for a variety of drug rewards including cocaine (Crombag et al., 2002; Fuchs et al., 2007; Hamlin et al., 2008), heroin (Bossert et al., 2004), alcohol (Burattini et al., 2006; Zironi et al., 2006; Hamlin et al., 2007; Marinelli et al., 2007), and nicotine (Diergaarde et al., 2008), as well as the natural reward sucrose (Hamlin et al., 2006). Renewal is a signature phenomenon of extinction (Bouton, 2002). It shows that extinction training does not erase the original learning that mediates drug seeking but instead imposes a mask on that learning to actively inhibit drug seeking in the extinction context.

Studies using microinjections of dopamine and glutamate receptor antagonists, as well as reversible inactivation via baclofen/

Received 0ct. 28, 2008; revised Nov. 25, 2008; accepted Dec. 20, 2008.

This work was supported by Grants 350879 and 510199 from the National Health and Medical Research Council to G.P.M. and by a University Postgraduate Award to N.J.M. We acknowledge Eun A Choi for her technical assistance.

Correspondence should be addressed to Dr. Gavan P. McNally, School of Psychology, The University of New South Wales, Sydney, 2052, Australia. E-mail: g.mcnally@unsw.edu.au.

DOI:10.1523/JNEUROSCI.5194-08.2009

Copyright $\odot 2009$ Society for Neuroscience $\quad$ 0270-6474/09/291331-12\$15.00/0 muscimol or tetrodotoxin infusion, have implicated hippocampus, basolateral amygdala (BLA), nucleus accumbens shell (AcbSh), nucleus accumbens core (AcbC), ventral tegmental area (VTA), and dorsomedial prefrontal cortex (dmPFC) in contextinduced reinstatement of drug seeking (Bossert et al., 2004, 2006, 2007; Fuchs et al., 2005, 2007, 2008). Recently, we have used c-Fos expression to identify the neural correlates of context-induced reinstatement. We have characterized these correlates for renewal of cocaine (Hamlin et al., 2008), alcoholic beer (Hamlin et al., 2007), and sucrose (Hamlin et al., 2006) seeking. In each case, renewal was selectively associated with c-Fos induction in lateral hypothalamus $(\mathrm{LH})$. To date there has been no investigation of the role of $\mathrm{LH}$ in renewal of extinguished drug seeking but a variety of additional lines of evidence support its potential involvement. For example, LH has long been implicated in regulating primary reward and feeding (Hoebel, 1979; Kelley, 2004) and, more recently, responding to drug-associated stimuli (Harris et al., 2005, 2007). Moreover, the neuropeptide orexin, which originates in hypothalamus, has been implicated in reinstatement of drug seeking. Stimulation of orexin receptors can reinstate conditioned place preference (Harris et al., 2005) whereas the orexin antagonist SB 334867 prevents cue or yohimbine induced reinstatement of extinguished alcohol seeking (Lawrence et al., 2006; Richards et al., 2008) as well as stress induced reinstatement of cocaine seeking (Boutrel et al., 2005).

We studied the role of LH in renewal of reward seeking for both a natural reward and a drug reward. We used complementary functional and neuroanatomical approaches to study the 
role of $\mathrm{LH}$ in renewal. First, we used infusions of muscimol/ baclofen to functionally inactivate LH on test. Second, we combined retrograde neuronal tracing from LH with a marker of cellular activation, c-Fos, to study activation of LH afferents during renewal.

\section{Materials and Methods}

Subjects. Subjects were experimentally naive male Long-Evans rats (250$350 \mathrm{~g}$ ) obtained from a commercial supplier (Monash Animal Services). After arrival, rats were housed in groups of eight in plastic cages. Rats in the beer experiment were maintained on a $12 \mathrm{~h}$ reverse light/dark cycle (lights on at 7:00 P.M.), whereas rats in the sucrose experiment were maintained on $12 \mathrm{~h}$ light/dark cycle (lights on at 7:00 A.M.). This difference in housing was due to laboratory renovation and did not impact on the results. The procedures were approved by the Animal Care and Ethics Committee at the University of New South Wales and conducted in accordance with the National Institutes of Health (NIH) Guide for the Care and Use of Laboratory Animals (NIH Publications No. 80-23), revised 1996. The procedures were designed to minimize the number of animals used.

Behavioral apparatus. For all experiments, training, extinction, and test were conducted in two sets of four chambers which differed in their visual (brightly lit vs dark), tactile (Perspex vs grid floors), and olfactory (rose oil vs peppermint essence) properties. For all chambers $[24 \mathrm{~cm}$ (length) $\times 30 \mathrm{~cm}$ (width) $\times 21 \mathrm{~cm}$ (height)], the front and rear walls as well as the roof were constructed of clear Perspex, and the end walls were made of stainless steel. In all chambers, two nose poke holes, containing a white cue-light, were located on one side wall of the chamber $3 \mathrm{~cm}$ above a grid floor. A recessed magazine was located behind a $4 \times 4 \mathrm{~cm}$ opening in the center of the same wall, between the two nose pokes. Responding on one (active) nose poke resulted in delivery of the reward to the magazine whereas responding on the other (inactive) nose poke had no programmable consequences. In one set of chambers the floor consisted of stainless steel rods, $4 \mathrm{~mm}$ in diameter, spaced $15 \mathrm{~mm}$ apart (center to center). These chambers were located in sound and light attenuating cabinets equipped with fans providing constant ventilation and low level background noise. There was no illumination in these chambers other than that provided by the white cue light recessed in the nose pokes. Dilute rose oil was placed in the bedding beneath these chambers. In the second set of chambers the floors consisted of Perspex. These chambers were located in sound and light attenuating cabinets equipped with fans providing constant ventilation and low level background noise. Illumination was provided by a $28 \mathrm{~V}$ house light. Dilute peppermint essence was placed in the bedding beneath the chambers. These two sets of chambers were fully counter-balanced to serve as contexts $\mathrm{A}$ and $\mathrm{B}$.

Behavioral testing procedures. The behavioral procedures were similar for all experiments. On the first $2 \mathrm{~d}$, the animals received 20 min magazine training sessions in both chambers. During these sessions, there were 10 noncontingent deliveries of $0.6 \mathrm{ml}$ of the reward $(4 \%$ alcohol $(\mathrm{v} / \mathrm{v})$ decarbonated beer or $10 \%$ sucrose $(\mathrm{w} / \mathrm{v})$ solutions) at time intervals variable around a mean of $1.2 \mathrm{~min}$. On the next $7 \mathrm{~d}$, animals were placed in Context A for $1 \mathrm{~h}$ per day. During this time responding on the active nose poke was rewarded, on an FR-1 schedule with $24 \mathrm{~s}$ timeout, by delivery of $0.6 \mathrm{ml}$ of the reward (beer or sucrose) to the magazine. Responses on the inactive nose poke were recorded but had no programmable consequences. For the next $4 \mathrm{~d}$, rats received extinction training in context B for $1 \mathrm{~h}$ per day. During this training, responses on either nose poke had no programmable consequences but were recorded. Rats in the beer experiment received $4 \mathrm{~d}$ of extinction training whereas rats in the sucrose experiment received $5 \mathrm{~d}$ of extinction training. This difference was due to more variable levels of responding during extinction training in the sucrose experiment. These parameters were chosen based on our past research which shows robust acquisition, extinction, and renewal of responding under these conditions (Hamlin et al., 2006, 2007, 2008). At the end of extinction training, rats were allocated, based on responding during acquisition and extinction training, to one of four groups: training context $\mathrm{A}(\mathrm{ABA}) \mathrm{B} / \mathrm{M}, \mathrm{ABA} \mathrm{PBS}$, extinction context $\mathrm{B}(\mathrm{ABB}) \mathrm{B} / \mathrm{M}$, or
ABB PBS. Twenty-four hours after the final extinction training session, rats were infused with either vehicle (PBS) or B/M (baclofen/muscimol), and then placed in either Context A or Context B for $1 \mathrm{~h}$. During this time, responses on either nose poke had no programmable consequences but were recorded.

Surgery. Before all behavioral testing, animals were either implanted with bilateral guide cannula directed toward the $\mathrm{LH}$, or received a unilateral microinjection of CTb in the LH. Rats were injected intraperitoneally with $1.3 \mathrm{ml} / \mathrm{kg}$ of the anesthetic ketamine (Ketapex; Apex Laboratories) at a concentration of $100 \mathrm{mg} / \mathrm{ml}$ and with $0.3 \mathrm{ml} / \mathrm{kg}$ of the muscle relaxant xylazine (Rompun; Bayer) at a concentration of $20 \mathrm{mg} / \mathrm{ml}$. Each rat was placed in the stereotaxic apparatus (Model 900, Kopf), and the incisor bar was maintained at $\sim 3.3 \mathrm{~mm}$ below horizontal to achieve a flat skull position.

Rats in the LH inactivation studies were implanted with bilateral cannula directed at the LH. A hand drill was used to expose the brain surface and a 26-gauge guide cannula (Plastics One) was implanted in each LH [anterior (A)-posterior (P): -2.3; medial (M)-lateral (L): $-3.4\left(10^{\circ}\right.$ angle); dorsal (D)-ventral (V): -7.5 ; distances in $\mathrm{mm}$ from bregma[. To control for diffusion, 6 rats were implanted with cannulae placed $2 \mathrm{~mm}$ dorsal to the LH (A-P: -2.3 ; M-L: -3.4 (10 ${ }^{\circ}$ angle); D-V: -5.5 ; distances in $\mathrm{mm}$ from bregma). The guide cannula was fixed in position with dental cement and anchored with jeweller's screws. A dummy cannula was kept in the guide at all times, except during microinjections.

Rats in the retrograde tracing experiment received microinjections of $\mathrm{CTb}$ to the right LH. A 30-gauge needle attached to a $1 \mu \mathrm{l}$ Hamilton syringe was lowered into the right LH (A-P: -2.3 ; M-L: -1.8 ; D-V: -8.6; distances in $\mathrm{mm}$ from bregma) and $40 \mathrm{nl}$ of $1 \%$ low salt $\mathrm{CTb}$ (List Biological Laboratories) was injected using a manual stereotaxic injector (Stoelting). Injections were conducted over $1 \mathrm{~min}$ and the needle was left in place for $10 \mathrm{~min}$ before removal to allow for diffusion and to reduce spread up the injection tract.

Immediately after surgery, rats received intramuscular injections of $0.15 \mathrm{ml}$ of a $300 \mathrm{mg} / \mathrm{ml}$ solution of procaine penicillin and $0.1 \mathrm{ml}$ of 100 $\mathrm{mg} / \mathrm{ml}$ cephazolin sodium, and subcutaneous injections of $5 \mathrm{mg} / \mathrm{kg}$ carprofen. Rats were allowed $5 \mathrm{~d}$ to recover from surgery, during which time they were weighed daily. At the conclusion of the LH inactivation experiments, rats were given an overdose of sodium pentobarbital, and their brains were removed. Unfixed brains were sectioned coronally at 40 $\mu \mathrm{m}$ through the LH. Every third section through the cannula placements in LH was collected on a glass slide and subsequently stained with cresyl violet. Cannula placements were verified at the microscope by the boundaries defined by Paxinos and Watson (1997).

Infusions. For intracranial infusions, the injection cannulae were connected to $10 \mu \mathrm{l}$ Hamilton syringes mounted on an infusion pump. A combination of baclofen (1.0 mm; Sigma-Aldrich) and muscimol hydrobromide ( $0.1 \mathrm{~mm}$; Sigma-Aldrich) or PBS vehicle, $\mathrm{pH}=7.2$, were infused at volumes of $0.5 \mu \mathrm{l}$ over $2 \mathrm{~min}$, and the injection cannulae left in place for $2 \mathrm{~min}$ after the infusion. To minimize unintended spread, we used a dose of $\mathrm{B} / \mathrm{M}$ that has been used in the past to demonstrate functional differentiation between the nucleus accumbens core and shell (Fuchs et al., 2008). To explicitly control for diffusion, rats in the beer experiment had cannulae directed dorsal (the most likely location of diffusion) to the $\mathrm{LH}$. These rats were injected with $\mathrm{B} / \mathrm{M}$ before test.

Immunohistochemistry. Rats in the retrograde tracing experiment were returned to their home cage at the end of the $1 \mathrm{~h}$ test session. At $2 \mathrm{~h}$ after being placed in the testing chambers, rats were deeply anesthetized with sodium pentobarbital (100 mg/kg, i.p.) and perfused transcardially with $50 \mathrm{ml}$ of $0.9 \%$ saline, containing $1 \%$ sodium nitrite and heparin (5000 i.u./ml), followed by $400 \mathrm{ml}$ of $4 \%$ paraformaldehyde in $0.1 \mathrm{M}$ phosphate buffer (PB), pH 7.4. Brains were postfixed for $1 \mathrm{~h}$ in the same fixative and placed in $20 \%$ sucrose solution overnight. Brains were blocked using a matrix aligned to the atlas of Paxinos and Watson (1997), and $40 \mu \mathrm{m}$ coronal sections were cut using a cryostat (Microm HM560, Microm International). Four serially adjacent sets of sections were obtained from each brain and stored in $0.1 \%$ sodium azide in $0.1 \mathrm{~m}$ PBS, pH 7.2. One series of sections through the $\mathrm{LH}$ was selected from each rat and immunofluorescence was used to determine $\mathrm{CTb}$ injection sites. Free-floating sections were washed repeatedly in $0.1 \mathrm{M}$ PBS, pH 7.2, followed by a $2 \mathrm{~h}$ 
incubation in PBS, pH 7.2, containing 10\% NHS and 0.5\% Triton X-100. Sections were then incubated in goat anti-choleragenoid (1:5000; List Biological Laboratories), diluted in $0.1 \mathrm{M}$ PBS, pH 7.2, containing $0.1 \%$ sodium azide, $2 \% \mathrm{NHS}$ and $0.2 \%$ Triton X-100, and incubations were for $48 \mathrm{~h}$ at room temperature, with gentle agitation. After washing off unbound primary antibodies, sections were then incubated for $4 \mathrm{~h}$ at room temperature in donkey anti-sheep FITC (1:500; Jackson Immunoresearch Laboratories), diluted in 2\% NHS PBT-X. After washing off unbound secondary antibodies, sections were mounted onto gelatintreated slides and coverslipped with buffered glycerol, $\mathrm{pH}$ 8.6.

A second series of sections was used to reveal c-Fos in combination with $\mathrm{CTb}$ using two-color peroxidase immunohistochemistry. Freefloating sections were washed repeatedly in $0.1 \mathrm{M} \mathrm{PB}, \mathrm{pH} 7.4$, followed by two 30 min washes in 50\% ethanol, the second of which contained $3 \%$ $\mathrm{H}_{2} \mathrm{O}_{2}$, and were then incubated in 5\% normal horse serum (NHS) in PB, $\mathrm{pH}$ 7.4, for $30 \mathrm{~min}$. Sections were incubated in rabbit antiserum against c-Fos (1:5000; c-Fos (4), s.c.-52, Santa Cruz Biotechnologies), which was mixed with goat anti-choleragenoid (1:5000; List Biological Laboratories). These primary antibodies were diluted in $0.1 \mathrm{M} \mathrm{PB}, \mathrm{pH} 7.4$, containing $2 \%$ NHS and $0.2 \%$ Triton X-100 (PBT-X), and incubations were for $48 \mathrm{~h}$ at $4^{\circ} \mathrm{C}$, with gentle agitation. After washing off unbound primary antibodies, sections were incubated overnight at room temperature in biotinylated donkey anti-rabbit IgG (1:1000; Jackson Immunoresearch Laboratories) diluted in 2\% NHS PBT-X. After washing off unbound secondary antibody, sections were incubated for $2 \mathrm{~h}$ at room temperature in $\mathrm{ABC}$ reagent (Vector Elite kit: $6 \mu \mathrm{l} / \mathrm{ml}$ avidin and $6 \mu \mathrm{l} / \mathrm{ml}$ biotin; Vector Laboratories). Black immunoreactive (IR) nuclei labeled for c-Fos were revealed by a nickel-intensified diaminobenzidine reaction, with peroxide being generated by glucose oxidase. To do this sections were washed in $\mathrm{PB}$, followed by $0.1 \mathrm{M}$ acetate buffer, $\mathrm{pH} 6.0$, and then incubated for $15 \mathrm{~min}$ in $0.1 \mathrm{M}$ acetate buffer, $\mathrm{pH} 6.0$, containing $2 \%$ nickel sulfate, $0.025 \%$ 3,3-diaminobenzidine, $0.004 \%$ ammonium chloride, and $0.02 \%$ D-glucose. The peroxidase reaction was started by adding 0.2 $\mu \mathrm{l} / \mathrm{ml}$ glucose oxidase and stopped using acetate buffer, $\mathrm{pH}$ 6.0. Brain sections were then washed in $\mathrm{PB}$ and processed again, in a similar manner using biotinylated donkey anti-sheep IgG (1:1000; Jackson Immunoresearch Laboratories) but without nickel-intensification to localize IR for $\mathrm{CTb}$, revealed as a brown reaction product. Sections were mounted onto gelatin-treated slides, dehydrated, cleared in histolene, and coverslipped with DePeX.

Neuronal counting. Counts of neurons IR for c-Fos and CTb were conducted through the rostro-caudal extent of each brain region of interest by an observer unaware of group allocations. All sections counted were $160 \mu \mathrm{m}$ apart. The brain regions analyzed were: prelimbic and infralimbic cortex over four sections beginning at $+3.20 \mathrm{~mm}$; nucleus accumbens core and shell over six sections beginning at $+1.70 \mathrm{~mm}$; paraventricular thalamus anterior over six sections beginning at -1.3 $\mathrm{mm}$, middle over 3 sections beginning at $-2.30 \mathrm{~mm}$, posterior over four sections beginning at $-3.14 \mathrm{~mm}$; ventral tegmental area over six sections beginning at $-5.20 \mathrm{~mm}$; dorsal raphe over 6 sections beginning at -7.30 $\mathrm{mm}$; locus ceruleus over six sections beginning at $-9.16 \mathrm{~mm}$. All coordinates given are distance from bregma according to the rat brain atlas of Paxinos and Watson (1997).

Data analysis. The numbers of responses were recorded during training, extinction, and test. These data were analyzed by means of planned orthogonal contrast testing procedure that preserved the factorial design. The planned orthogonal contrast testing procedure generates $1 \mathrm{df}$ for $\nu_{1}$ with $\nu_{2}$ defined normally as $\mathrm{J}(n-1)$ (Harris, 1994). A multivariate approach to repeated measures was adopted which treats each family of within subject contrasts (i.e., main effects on days, manipulanda, and their associated interaction terms) with their own error terms generating a more powerful analysis of repeated measures data (O'Brien and Kaiser, 1985). The type I error rate $(\alpha)$ was controlled at 0.05 for each contrast tested (Harris, 1994). The reader is referred to Harris (1994) and O'Brien and Kaiser (1985) for detailed descriptions of these analyses. The means of the total counts of c-Fos-IR, CTb-IR, and c-Fos/CTb double-IR neurons in each brain region were analyzed by ANOVA.

\section{Results \\ Functional inactivation of the LH during context-induced reinstatement of sucrose seeking}

In this experiment rats were implanted with bilateral cannulae targeting LH. They were then trained to respond for $10 \%$ sucrose in context A before extinction training in a second, different context, context $\mathrm{B}$. Half the rats were tested for responding in the extinction context $(\mathrm{ABB})$ whereas the remainder were tested for responding in context $A$ ( $A B A$ ). Rats in each group received infusions of either the $\mathrm{GABA}_{\mathrm{B}}$ agonist baclofen and $\mathrm{GABA}_{\mathrm{A}}$ agonist muscimol or PBS into LH before test.

\section{Histology}

Figure $1 A-E$ shows bilateral injection cannula placements. The plotted points represent the ventral point of the cannula track. Six rats were excluded from the primary analyses due to misplaced cannulae. Of these rats, four were in group ABA-B/M. The data from these rats, group ABA-B/M Misplaced, were used in secondary analyses to confirm the neuroanatomical specificity of the effects observed. Figure $1 E$ shows cannula placements for group ABA-B/M Misplaced. The final group sizes were: $\mathrm{ABA} B / \mathrm{M}, n=$ 6; ABA PBS, $n=7$; $\mathrm{ABB} \mathrm{B} / \mathrm{M}, n=6$; $\mathrm{ABB} \operatorname{PBS} n=6$; $\mathrm{ABA} \mathrm{B} / \mathrm{M}$ Misplaced, $n=4$.

\section{Behavior}

All rats acquired high levels of responding during training. The mean volume of sucrose earned and consumed per $1 \mathrm{~h}$ session was $21.73 \mathrm{ml}$, there were no difference across groups in the total sucrose earned $\left(F_{(1,21)}<1 ; p>0.05\right)$, and total active nose pokes per session $\left(F_{(1,21)}<1 ; p>0.05\right)$. The left panel of Figure $1 F$ shows the mean $( \pm \mathrm{SEM})$ levels of responding across the five extinction days. There were no differences between groups during extinction $\left(F_{(1,21)}<1 ; p>0.05\right)$ so the data were collapsed across the four groups (ABA B/M; ABA PBS; ABB B/M; ABB PBS) in Figure $1 F$. During extinction, there was significantly more responding on the active than inactive nose poke, averaged across days $\left(F_{(1,21)}=114.1 ; p<0.0001\right)$. There was a significant decrease in overall levels of responding across extinction training $\left(F_{(1,21)}=79.7 ; p<0.0001\right)$. There was a significant interaction so that the decrease in responding on the active nose poke was greater than the inactive nose poke across the course of extinction training $\left(F_{(1,21)}=97.9 ; p<0.0001\right)$.

The right panel of Figure $1 F$ shows the mean ( \pm SEM) levels of responding on test. There was an overall significant difference in level of responding between groups $\mathrm{ABA}$ and groups $\mathrm{ABB}\left(F_{(1,21)}\right.$ $=27.4 ; p<0.0001)$. There was an overall significant difference in level of responding between groups $\mathrm{B} / \mathrm{M}$ and groups $\mathrm{PBS}\left(F_{(1,21)}\right.$ $=11.1 ; p<0.01)$. There was an overall significant difference in responding on the active versus inactive nose poke $\left(F_{(1,21)}=58.6\right.$; $p<0.0001)$. Finally, there was a significant three-way interaction between infusion type, context of test, and manipulanda which shows that the reduction in renewal in group ABA B/M was specific to the active nose poke $\left(F_{(1,21)}=9.59 ; p<0.01\right)$. Further analyses confirmed the presence of renewal and its attenuation by $\mathrm{LH} \mathrm{B} / \mathrm{M}$. There was significantly more responding on the active nose poke in group ABA PBS versus group $\mathrm{ABB}$ PBS $\left(F_{(1,21)}=\right.$ 38.02; $p<0.0001)$. Infusion of $\mathrm{B} / \mathrm{M}$ into $\mathrm{LH}$ prevented this renewal because there was significantly less responding on the active nose poke in group ABA B/M versus group ABA PBS $\left(F_{(1,21)}\right.$ $=21.92 ; p<0.0001)$. There was no significant difference in active nose poke responding between groups $\mathrm{ABB} P B S$ and $\mathrm{ABB}$ $\mathrm{B} / \mathrm{M}\left(F_{(1,21)}<1 ; p>0.05\right)$. This demonstrates that bilateral 


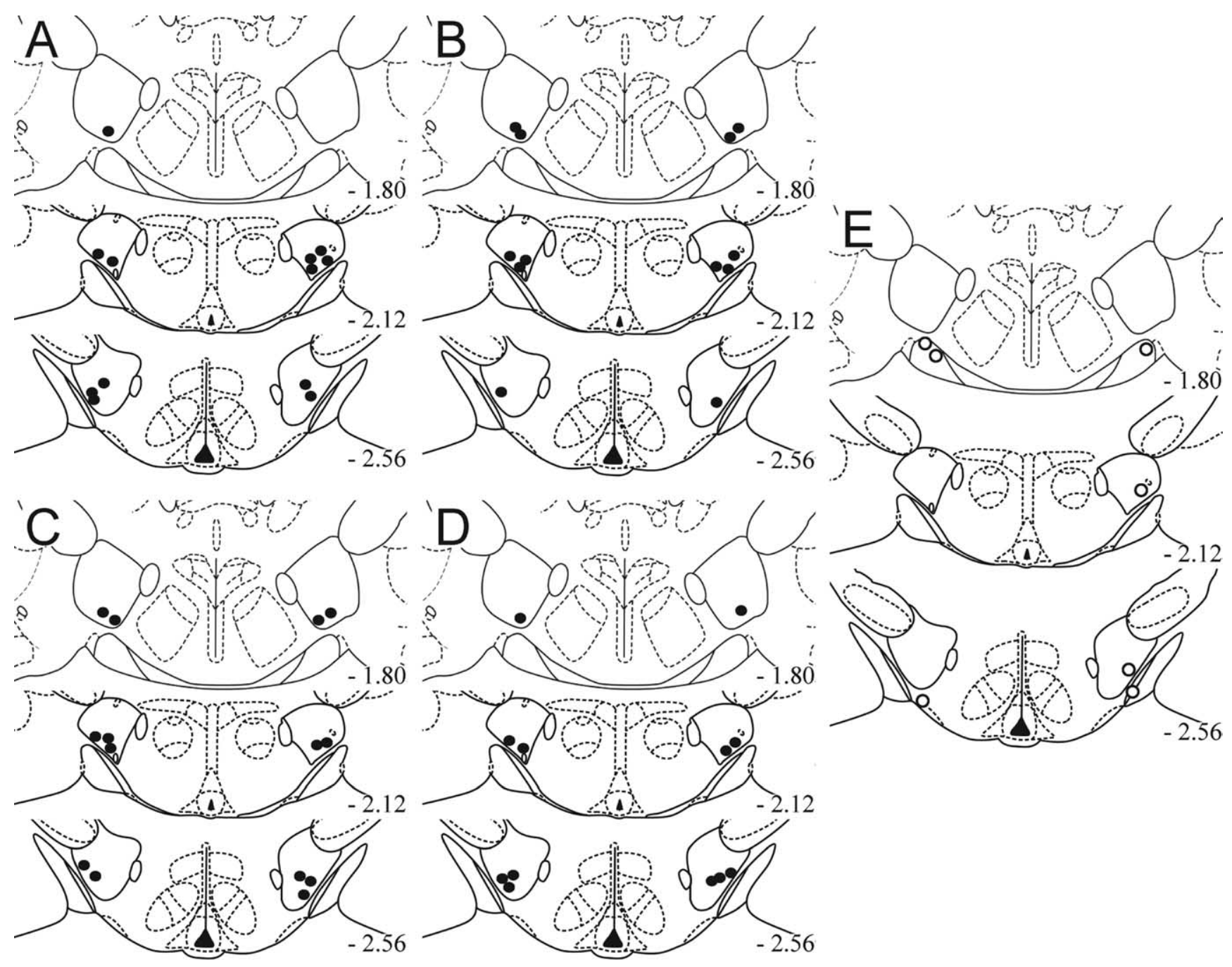

F Extinction

Test

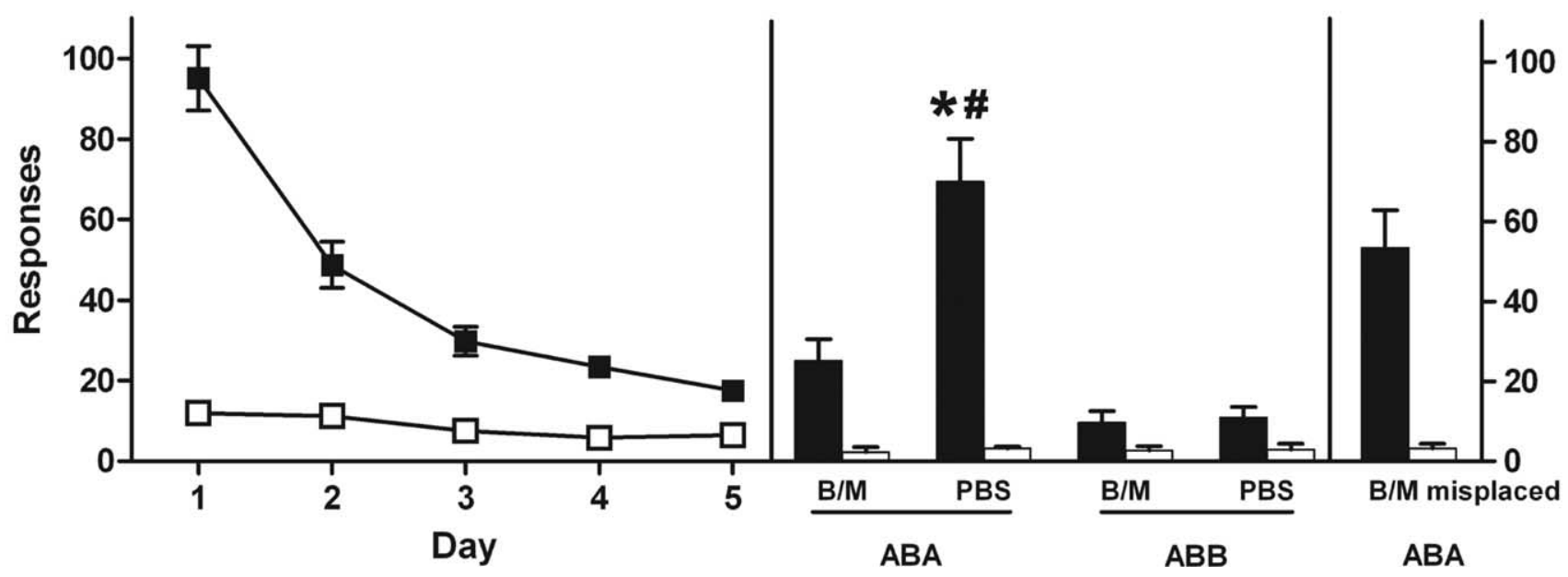

Figure 1. Effect of $L H$ inactivation on renewal of sucrose seeking. $A-E$, Microinfusion cannula placements as verified on Nissl-stained section for group $A B A B / M(A)$, $A B B B / M(B)$, $A B A$ PBS $(\boldsymbol{C})$, ABB PBS (D), and ABA B/M Misplaced (E). The symbols represent the most ventral point of the cannula track for each rat on coronal sections based on the atlas of Paxinos and Watson (1997). Closed circles denote correct cannula placements, open circles denote the cannula placements of ineffective B/M infusions. Numbers indicate distance from Bregma in millimeters. $\boldsymbol{F}$, Mean ( \pm SEM) responses on the active (closed squares) and inactive (open squares) nose pokes during extinction (left) and test (right). Rats were trained in context $A$, extinguished in context $B$, and then tested in either context $\mathrm{A}$ (groups $\mathrm{ABA}$ ) or context B (groups ABB). Before the test, rats received infusions of either B/M (baclofen/muscimol) or PBS. Return to the original training context after extinction resulted in renewal of sucrose seeking. This was prevented in rats that received bilateral infusions of B/M into the LH. Symbols represent significant difference of active nose pokes in the test session relative to the ABA PBS group for ABA B/M ( $\left.{ }^{*} p<0.0001\right)$, and ABB PBS $\left({ }^{\#} p<0.0001\right)$. 
inactivation of $\mathrm{LH}$ before test selectively reduces renewed responding on the active nose poke.

The neuroanatomical specificity of the effect of bilateral LH infusions of $\mathrm{B} / \mathrm{M}$ was confirmed by analyzing data from group ABA B/M Misplaced. The level of responding in this group was no different from group ABA PBS $\left(F_{(1,8)}<1\right.$; $\left.p>0.05\right)$. In contrast, there was a significant difference between group $\mathrm{ABA}$ $\mathrm{B} / \mathrm{M}$ and group $\mathrm{ABA} \mathrm{B} / \mathrm{M}$ Misplaced $\left(F_{(1,8)}=8.56 ; p<0.05\right)$. This shows that infusions of $\mathrm{B} / \mathrm{M}$ into regions near the $\mathrm{LH}$ had no effect on context-induced reinstatement. It confirms the neuroanatomical specificity of the disruption of renewal by bilateral $\mathrm{B} / \mathrm{M}$ infusion into $\mathrm{LH}$.

\section{Functional inactivation of the $\mathrm{LH}$ during context-induced reinstatement of beer seeking}

In this experiment rats were implanted with bilateral cannulae targeting LH. They were then trained to respond for $4 \%$ alcoholic beer in context A before extinction training in a second, different context, context $\mathrm{B}$. Half the rats were tested for responding in $\mathrm{ABB}$, whereas the remainder were tested for responding in $\mathrm{ABA}$. Rats in each group received infusions of either the $\mathrm{GABA}_{\mathrm{B}}$ agonist baclofen and $\mathrm{GABA}_{\mathrm{A}}$ agonist muscimol or PBS into LH before test.

\section{Histology}

Figure $2 A-F$ shows bilateral injection cannula placements. The plotted points represent the ventral point of the cannula track. 14 rats were excluded from the primary analyses due to misplaced cannulae. Of these rats, 5 were in group ABA B/M and each of these rats had one correct and one misplaced cannula (Fig. $1 E$ ). The data from these rats, group ABA UNI B/M, were used in secondary analyses to confirm the neuroanatomical specificity of the effects observed. The final groups sizes were: group $\mathrm{ABA} B / \mathrm{M}$, $n=6$; $\mathrm{ABA}$ PBS, $n=7$; $\mathrm{ABB} \mathrm{B} / \mathrm{M}, n=6$; $\mathrm{ABB} \operatorname{PBS} n=7$; $\mathrm{ABA}$ $\mathrm{UNI} \mathrm{B} / \mathrm{M}, n=5$; ABA Dorsal $\mathrm{B} / \mathrm{M}, n=6$.

\section{Behavior}

All rats acquired high levels of responding during training. The mean volume of beer earned and consumed in each $1 \mathrm{~h}$ acquisition session was $22.0 \mathrm{ml}(0.88 \mathrm{ml}$ of $100 \% \mathrm{EtOH})$, there were no difference across groups in the total beer earned $\left(F_{(1,22)}<1.7\right.$; $p>0.05)$, and total active nose pokes per session $\left(F_{(1,22)}<1 ; p>\right.$ 0.05 ). The left panel of Figure $2 G$ shows the mean ( \pm SEM) levels of responding across the four extinction days. There were no differences between groups during extinction $\left(F_{(1,22)}<1 ; p>\right.$ 0.05 ) so the data were collapsed across the four groups (ABA $\mathrm{B} / \mathrm{M}, \mathrm{ABA}$ PBS, ABB B/M, ABB PBS) in Figure 2G. During extinction, there was significantly more responding on the active than inactive nose poke, averaged across days $\left(F_{(1,22)}=61.53\right.$; $p<0.0001)$. There was a significant decrease in overall levels of responding across extinction training $\left(F_{(1,22)}=72.08 ; p<\right.$ $0.0001)$. There was a significant interaction so that the decrease in responding on the active nose poke was greater than the inactive nose poke across the course of extinction training $\left(F_{(1,22)}=\right.$ 90.72; $p<0.0001)$.

The right panel of Figure $2 G$ shows the mean ( \pm SEM) levels of responding on test. There was an overall significant difference in level of responding between group $\mathrm{ABA}$ and group $\mathrm{ABB}\left(F_{(1,22)}=\right.$ $10.04 ; p<0.01)$. There was an overall significant difference in level of responding between group $\mathrm{B} / \mathrm{M}$ and group $\mathrm{PBS}\left(F_{(1,22)}=\right.$ $6.54 ; p<0.05)$. There was an overall significant difference in responding on the active versus inactive nose poke $\left(F_{(1,22)}=\right.$ $13.85 ; p<0.001)$. Finally, there was a significant three-way inter- action between infusion type, context of test, and manipulanda which shows that the reduction in responding in group $\mathrm{ABA} B / \mathrm{M}$ was specific to the active nose poke $\left(F_{(1,22)}=8.05 ; p<0.05\right)$. Further analyses confirmed the presence of renewal and its attenuation by $\mathrm{LH} \mathrm{B} / \mathrm{M}$. There was significantly more responding on the active nose poke in group ABA PBS versus group ABB PBS $\left(F_{(1,22)}=18.49 ; p<0.0001\right)$. Infusion of $\mathrm{B} / \mathrm{M}$ into $\mathrm{LH}$ prevented this renewal because there was significantly less responding on the active nose poke in group $\mathrm{ABA} \mathrm{B} / \mathrm{M}$ versus group $\mathrm{ABA} \mathrm{PBS}$ $\left(F_{(1,22)}=15.62 ; p<0.001\right)$. There was no significant difference in active nose poke responding between groups $\mathrm{ABB} P B S$ and $\mathrm{ABB}$ $\mathrm{B} / \mathrm{M}\left(F_{(1,22)}<1 ; p>0.05\right)$. This demonstrates that bilateral inactivation of $\mathrm{LH}$ before test selectively reduces renewed responding on the active nose poke.

The neuroanatomical specificity of the effect of bilateral $\mathrm{LH}$ infusions of $\mathrm{B} / \mathrm{M}$ was confirmed by controls which included infusions $2 \mathrm{~mm}$ dorsal to the $\mathrm{LH}$, or unilateral inactivation of $\mathrm{LH}$. The level of responding on $\mathrm{ABA}$ test in rats that received bilateral infusions of B/M $2 \mathrm{~mm}$ dorsal to $\mathrm{LH}$ was no different from rats that received bilateral infusions of PBS into $\mathrm{LH}\left(F_{(1,11)}<1 ; p>\right.$ $0.05)$. In contrast, there was a significant difference in responding on $\mathrm{ABA}$ test between rats that received bilateral infusions of $\mathrm{B} / \mathrm{M}$ into $\mathrm{LH}$ and rats that received bilateral infusions of $\mathrm{B} / \mathrm{M} 2 \mathrm{~mm}$ dorsal to $\operatorname{LH}\left(F_{(1,10)}=13.93 ; p<0.01\right)$. The level of responding on ABA test in rats that had unilateral inactivation of the $\mathrm{LH}$ due to one correctly placed cannula and one misplaced cannula was no different from rats that received bilateral infusions of PBS $\left(F_{(1,10)}<1 ; p>0.05\right)$. In contrast, there was a significant difference in levels of responding on ABA test between rats that received bilateral $\mathrm{B} / \mathrm{M}$ infusions into $\mathrm{LH}$ and rats that received unilateral B/M infusions into $\mathrm{LH}\left(F_{(1,9)}=14.05 ; p<0.01\right)$. These findings confirm the neuroanatomical specificity of the disruption of renewal by bilateral $\mathrm{B} / \mathrm{M}$ infusion into the $\mathrm{LH}$.

\section{Retrograde tracing from the $\mathrm{LH}$ during context-induced reinstatement of beer seeking}

In this experiment we combined retrograde neuronal tracing from $\mathrm{LH}$, using cholera toxin subunit B, with a marker of cellular activation, c-Fos, to identify activated LH afferents during renewal of beer seeking. We examined major afferents to the LH (Table 1) but focused especially on AcbSh. AcbSh is a major source of projections to LH (Heimer et al., 1991; Zahm and Brog, 1992; Zahm and Heimer, 1993; Kirouac and Ganguly, 1995; Usuda et al., 1998). Two groups, group ABA LH and group ABB $\mathrm{LH}$, received application of CTb tracer to $\mathrm{LH}$ before training and testing for $\mathrm{ABA}$ renewal as described previously. A third group, group $\mathrm{ABA} P \mathrm{PeF}$, received application of $\mathrm{CTb}$ tracer to the immediately adjacent perifornical hypothalamus $(\mathrm{PeF})$ before training and testing for renewal. Group ABA PeF was included to allow inferences about the neuroanatomical specificity of any double c-Fos/CTb labeling observed in group ABA LH.

\section{Behavior}

All rats acquired high levels of responding during training. The mean volume of beer earned and consumed in each $1 \mathrm{~h}$ acquisition session was $22.71 \mathrm{ml}(0.91 \mathrm{ml}$ of $100 \% \mathrm{EtOH})$, there were no difference across groups in the total beer earned $\left(F_{(1,8)}<1 ; p>\right.$ $0.05)$, and total active nose pokes per session $\left(F_{(1,8)}<1 ; p>\right.$ $0.05)$. The left panel of Figure $3 A$ shows the mean $( \pm S E M)$ responses during extinction and test. There were no overall differences between groups during extinction $\left(F_{(1,8)}<1 ; p>0.05\right)$. There was significantly more responding on the active than inactive nose poke, averaged across days of extinction $\left(F_{(1,8)}=59.3\right.$; 

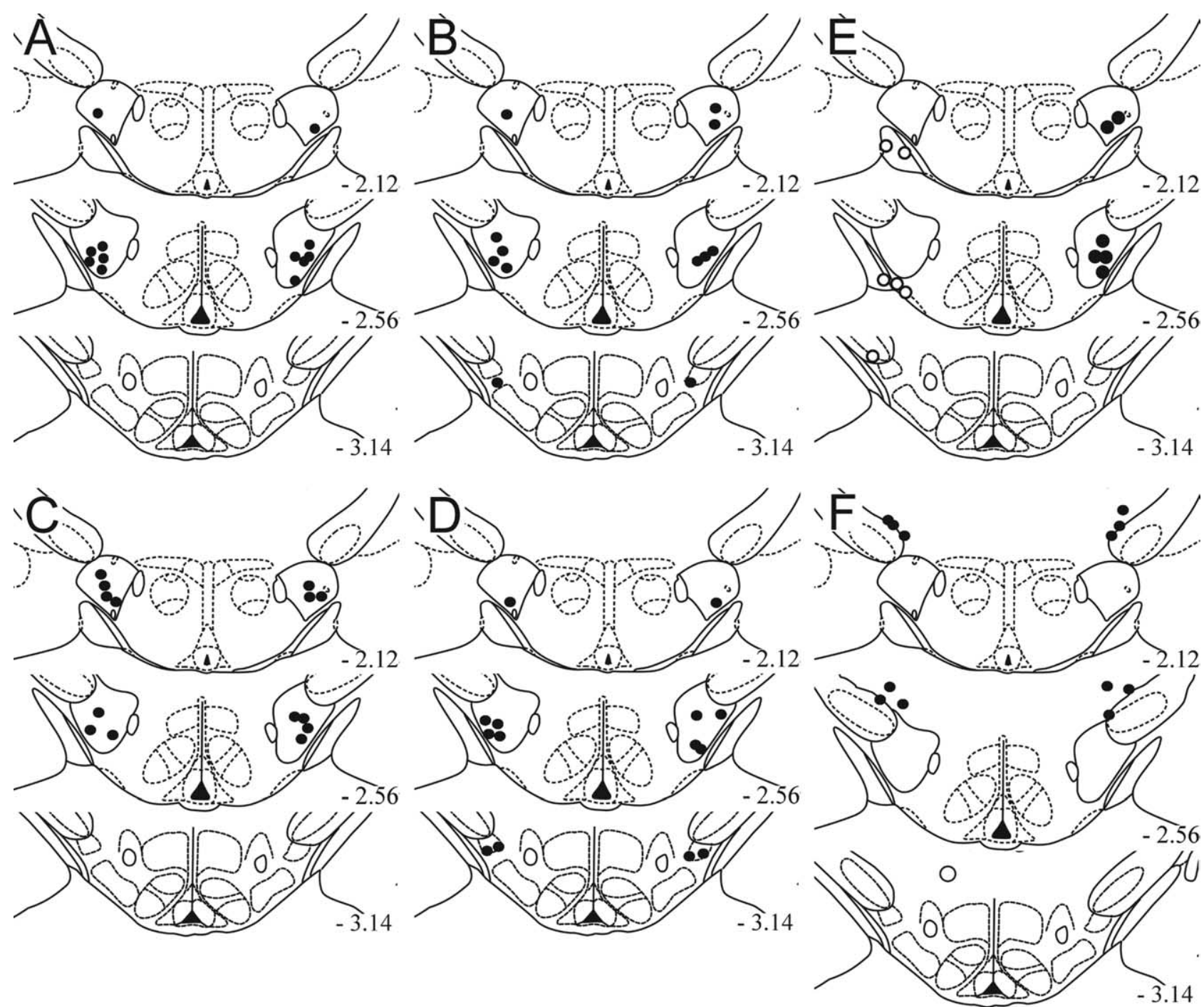

G Extinction

Test

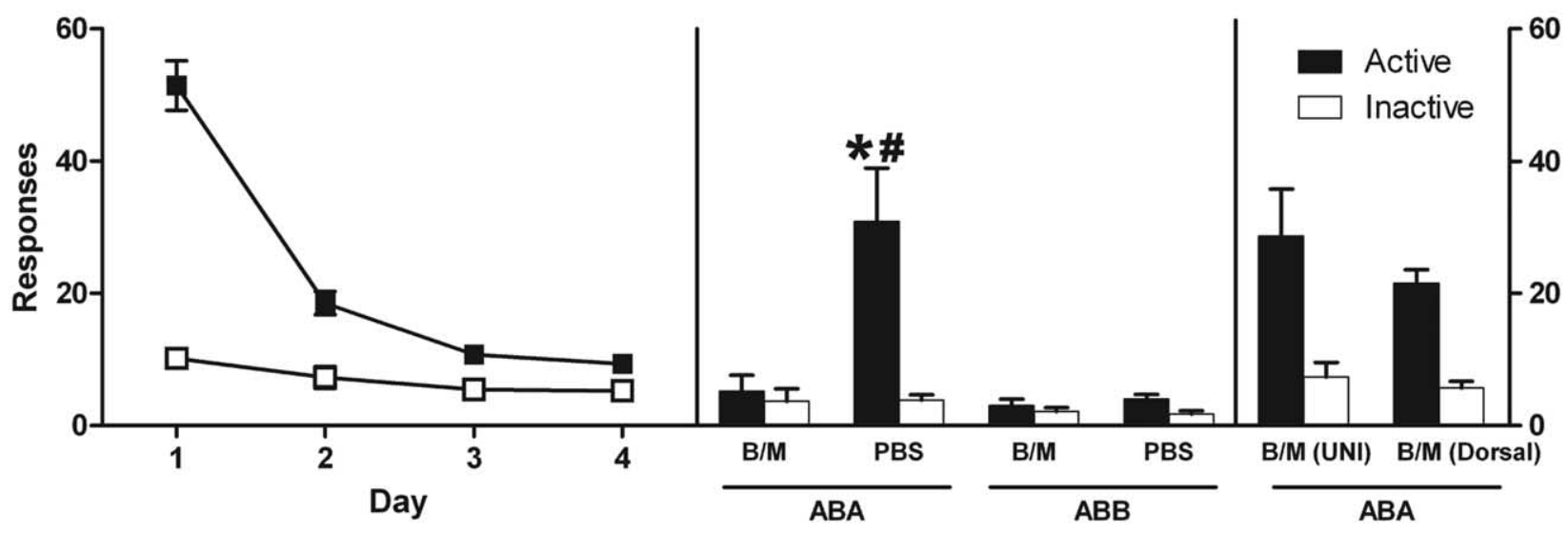

Group

Figure 2. Effect of $L$ inactivation on renewal of alcoholic beer seeking. $A-F$, Microinfusion cannula placements as verified on Nissl-stained sections for group $A B A B / M(A), A B B B / M(B), A B A P B S$ $(\boldsymbol{C}), A B B P B S(\boldsymbol{D}), A B A B / M U N I(\boldsymbol{E})$, and ABA B/M dorsal $(\boldsymbol{F})$. The symbols represent the most ventral point of the cannula track for each rat on coronal sections based on the atlas of Paxinos and Watson (1997). The cannula placements in $\boldsymbol{E}$ are from rats with one correctly placed cannula (closed circle) and one misplaced cannula (open circle). Numbers indicate the distance from Bregma in millimeters. G, Mean ( \pm SEM) responses on the active (closed squares) and inactive (open squares) nose pokes during extinction (left) and test (right). Rats were trained in context $A$, extinguished in context $B$, and then tested in either context $A$ (groups $A B A$ ) or context $B$ (groups $A B B$ ). Prior to test, rats received microinfusions of either B/M or PBS. Return to the original training context after extinction resulted in renewal. This was prevented in rats that received bilateral, but not unilateral, infusions of B/M into the LH. Infusions of B/M $2 \mathrm{~mm}$ dorsal to the $L H$ did not disrupt renewal. Symbols represent significant difference of active nose pokes in the test session relative to the ABA PBS group for ABA B/M ( $\left.{ }^{*} p<0.001\right)$, and ABB PBS $\left({ }^{\#} p<0.0001\right)$. 
Table 1. Mean and SEM counts of total c-Fos- and CTb-labeled neurons after CTB injection into LH or PeF

\begin{tabular}{|c|c|c|c|c|}
\hline & \multicolumn{2}{|l|}{ c-Fos } & \multicolumn{2}{|l|}{$\mathrm{CTb}$} \\
\hline & $\mathrm{ABA}(n=8)$ & $\mathrm{ABB}(n=3)$ & 나 $(n=7)$ & $\operatorname{PeF}(n=4)$ \\
\hline AcbShDm & $108.9(9.9)$ & $89.0(19.5)$ & $200.4(15.9)$ & 55.5 (13.8) \\
\hline AcbShV & $100.9(9.9)$ & $44.0(5.0)$ & $307.7(36.7)$ & $58.0(14.5)$ \\
\hline $\mathrm{AcbC}$ & 111.3 (14.6) & $101.3(9.3)$ & $207.6(45.2)$ & $3.0(2.7)$ \\
\hline plPFc & 199.6 (26.2) & $155.0(24.8)$ & $154.6(25.3)$ & $203.5(6.9)$ \\
\hline ilPFc & 124.8 (16.1) & 106.3 (17.3) & $141.0(12.8)$ & $154.0(18.9)$ \\
\hline PVTa & $223.3(20.5)$ & $193.0(12.5)$ & 87.9 (11.2) & 119.7 (19.5) \\
\hline PVTm & 102.9 (10.6) & 104.3 (11.9) & $42.6(6.6)$ & 41.7 (3.2) \\
\hline PVTp & 117.8 (11.3) & $109.7(12.0)$ & $54.0(5.3)$ & $52.7(19.2)$ \\
\hline VTA & $48.1(11.3)$ & $37.0(9.5)$ & $79.6(9.7)$ & $64.3(7.0)$ \\
\hline DR & 82.4 (15.5) & 59.3 (12.4) & $177.0(7.0)$ & $122.0(8.7)$ \\
\hline $\mathrm{LC}$ & 15.9 (3.7) & $15.3(7.1)$ & $77.0(7.6)$ & $66.3(2.8)$ \\
\hline
\end{tabular}

$p<0.0001)$. There was a significant decrease in overall levels of responding across days of extinction training $\left(F_{(1,8)}=29.1 ; p<\right.$ $0.001)$. There was a significant interaction so that the decrease in responding on the active nose poke was greater than the inactive nose poke across the course of extinction training $\left(F_{(1,8)}=31.3\right.$; $p<0.001)$. There was no significant difference across extinction for the different groups $\left(F_{(1,8)}<1 ; p>0.05\right)$.

For test, there was an overall significant difference in level of responding between group $\mathrm{ABA}$ and group $\mathrm{ABB}\left(F_{(1,8)}=6.2 ; p<\right.$ $0.05)$. There was also an overall significant difference in responding on the active versus inactive nose poke $\left(F_{(1,8)}=30.9 ; p<\right.$ $0.001)$. Finally, there was a significant interaction, so that the increase in responding during test in context A was specific for the active nose poke $\left(F_{(1,8)}=10.5 ; p<0.05\right)$. This confirms renewal of extinguished beer seeking.

\section{Injections sites and distribution of retrograde- labeled neurons}

Figure 3, $B$ and $C$, shows photomicrographs of representative $\mathrm{CTb}$ injections in $\mathrm{LH}$ and $\mathrm{PeF}$, respectively. Figure 4 shows the maximum spread of each individual case of CTb injection plotted on coronal sections based on the atlas of Paxinos and Watson (1997). Five rats were excluded from the analysis due to CTb injections spreading beyond the boundaries of either LH or PeF. The distribution of retrograde-labeled CTb-IR neurons after $\mathrm{CTb}$ injection into LH was similar to previous studies (Petrovich et al., 2001; Hamlin et al., 2008) and included prefrontal cortex, nucleus accumbens, paraventricular thalamus, ventral tegmental area, dorsal raphe, and locus ceruleus. Figure $3 D$ shows a representative photomicrograph of Acb in rats with a CTb injection in $\mathrm{LH}$, and Figure $3 E$ shows a representative photomicrograph of Acb in rats with a CTb injection in PeF. Retrograde-labeled cells in Acb were more pronounced following CTb injection into LH than PeF.

\section{Distribution of c-Fos-IR in LH and PeF afferents}

Table 1 shows mean and SEM total c-Fos-IR and CTb-IR neurons for all brain regions examined. Table 2 shows the number of dual-IR c-Fos/CTb neurons, percentage of c-Fos-IR neurons labeled with $\mathrm{CTb}$-IR, and percentage of CTb-IR neurons labeled with c-Fos-IR. The initial analysis was based on counts of c-Fos$\mathrm{IR}, \mathrm{CTb}-\mathrm{IR}$, and c-Fos/CTb-IR neurons.

Figure $3 F$ shows mean $( \pm$ SEM) total c-Fos, single c-Fos, and dual c-Fos/CTb IR for AcbSh. Our past research has shown an important difference between c-Fos expression in ventral (Acb$\mathrm{ShV}$ ) and dorsomedial (AcbShDm) AcbSh during ABA renewal (Hamlin et al., 2007). We have previously shown that renewal associated c-Fos induction is detected only in AcbShV. We therefore examined c-FosIR, CTb-IR, and dual c-Fos/CTb-IR in AcbShV and AcbShDm separately.

In AcbShV there was a significant difference between groups $\mathrm{ABA}$ and $\mathrm{ABB}$ in total c-Fos-IR nuclei $\left(F_{(1,8)}=10.1 ; p<\right.$ $0.05)$. This replicates our previously published finding that renewal of beer seeking is associated with c-Fos induction in AcbShV (Hamlin et al., 2007). A similar significant difference between groups ABA and $\mathrm{ABB}$ was observed for single c-Fos-IR $\left(F_{(1,8)}=9.2 ; p<0.05\right)$. There were significantly more CTb-IR neurons in AcbShV after $\mathrm{CTb}$ injection in $\mathrm{LH}$ versus $\operatorname{PeF}\left(F_{(1,8)}\right.$ $=31.2 ; p<0.001)$, but no difference between groups ABA and $\mathrm{ABB}$ in total CTb-IR neurons after CTb injection in $\mathrm{LH}\left(F_{(1,8)}=\right.$ 4.4; $p>0.05)$. Importantly, there was a significant difference between groups $\mathrm{ABA}$ and $\mathrm{ABB}$ in $\mathrm{c}-\mathrm{Fos} / \mathrm{CTb}$ dual-IR $\left(F_{(1,8)}=\right.$ $10.3 ; p<0.05)$. This finding shows significantly greater $\mathrm{c}-\mathrm{Fos} /$ $\mathrm{CTb}$ dual-IR in group $\mathrm{ABA}$ versus group $\mathrm{ABB}$. This difference was specific to LH-projecting neurons because there were significantly greater c-Fos/CTb dual-IR neurons in group ABA following $\mathrm{CTb}$ injection into $\mathrm{LH}$ versus into $\operatorname{PeF}\left(F_{(1,8)}=18.7 ; p<\right.$ $0.01)$.

In AcbShDm there was no significant difference between groups $\mathrm{ABA}$ and $\mathrm{ABB}$ in total c-Fos-IR nuclei $\left(F_{(1,8)}<1 ; p>\right.$ $0.05)$. There was also no significant difference between groups $\mathrm{ABA}$ and $\mathrm{ABB}$ for single $\mathrm{c}$-Fos-IR nuclei $\left(F_{(1,8)}=2.1 ; p>0.05\right)$. There were significantly more CTb-IR neurons in AcbShDm after CTb injection in $\mathrm{LH}$ versus $\operatorname{PeF}\left(F_{(1,8)}=38.8 ; p<0.0001\right)$, but no difference between groups $\mathrm{ABA}$ and $\mathrm{ABB}$ in total CTb-IR neurons after CTb injection in $\mathrm{LH}\left(F_{(1,8)}=1.2 ; p>0.05\right)$. There were significantly more $\mathrm{c}-\mathrm{Fos} / \mathrm{CTb}$ dual-IR neurons after $\mathrm{CTb}$ injection into $\mathrm{LH}$ versus $\mathrm{PeF}\left(F_{(1,8)}=18.0 ; p<0.01\right)$. Importantly, there was also a significant difference between groups ABA and $\mathrm{ABB}$ in c-Fos/CTb dual-IR after CTb injection in LH: group $\mathrm{ABB}$ showed significantly greater c-Fos/CTb dual-IR than group $\operatorname{ABA}\left(F_{(1,8)}=8.3 ; p<0.05\right)$.

Recent research has implicated AcbC in renewal of extinguished cocaine seeking (Fuchs et al., 2008). We therefore also examined group differences in AcbC. Consistent with our past findings, there was no significant difference between groups ABA versus ABB in total $\left(F_{(1,8)}<1 ; p>0.05\right)$ or single c-Fos-IR nuclei $\left(F_{(1,8)}<1 ; p>0.05\right)$ in AcbC. There were significantly more $\mathrm{CTb}$-IR neurons in AcbC after CTb injection in $\mathrm{LH}$ versus $\mathrm{PeF}$ $\left(F_{(1,8)}=10.7 ; p<0.05\right)$, but no difference between groups ABA and $\mathrm{ABB}$ in total CTb-IR neurons after $\mathrm{CTb}$ injection in $\mathrm{LH}$ $\left(F_{(1,8)}=1.4 ; p>0.05\right)$. There was also no significant difference between groups $\mathrm{ABA}$ versus $\mathrm{ABB}$ in c-Fos/CTb dual-IR after $\mathrm{CTb}$ injection in $\mathrm{LH}\left(F_{(1,8)}<1 ; p>0.05\right)$.

The only other structure which revealed a significant difference between groups was the anterior portion of the paraventricular thalamus. In this region, there were significantly more c-Fos/CTb dual-IR neurons in group ABA after CTb injection into PeF versus groups $\mathrm{ABA}$ and $\mathrm{ABB}$ after $\mathrm{CTb}$ injection into $\mathrm{LH}$ $\left(F_{(1,8)}=10.2 ; p<0.05\right)$ but no difference between groups ABA and $\mathrm{ABB}$ after $\mathrm{CTb}$ injection into $\mathrm{LH}\left(F_{(1,8)}<1 ; p>0.05\right)$. This could indicate a role for projections from anterior paraventricular thalamus (PVT) to PeF in renewal but is difficult to interpret due to absence of an $\mathrm{ABB}$ group also injected with $\mathrm{CTb}$ into PeF. As noted above, Group ABA PeF was included to allow inferences 
A

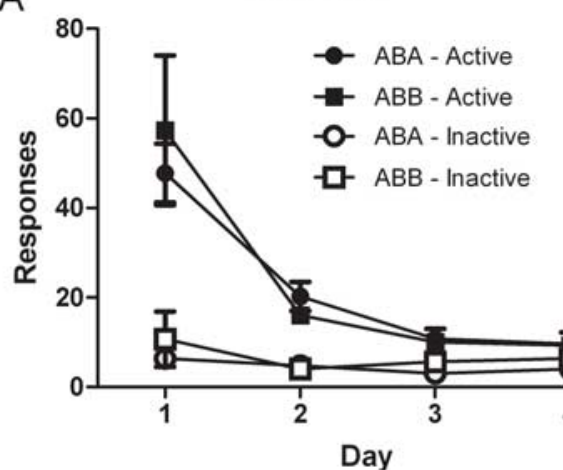

LH Injection

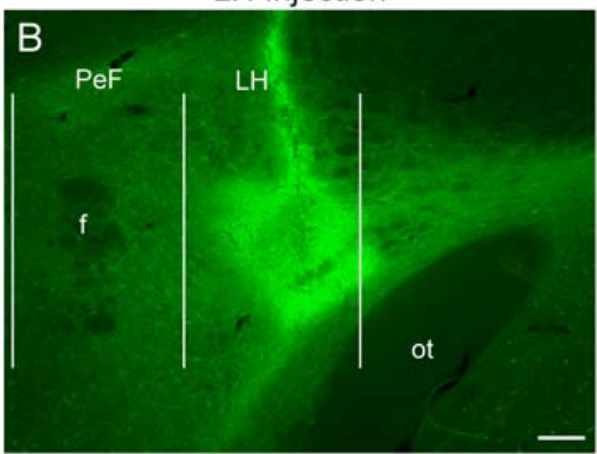

Test

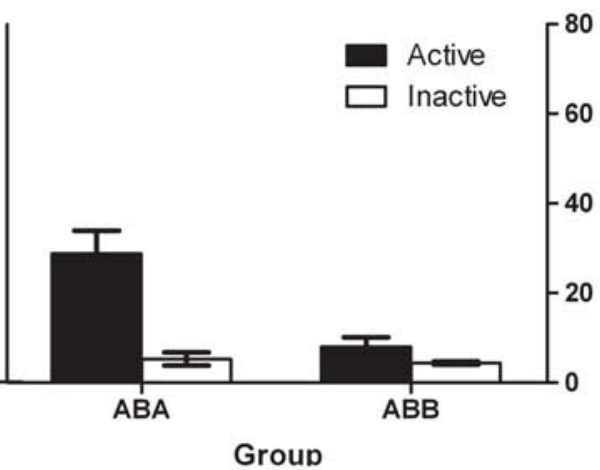

PeF Injection

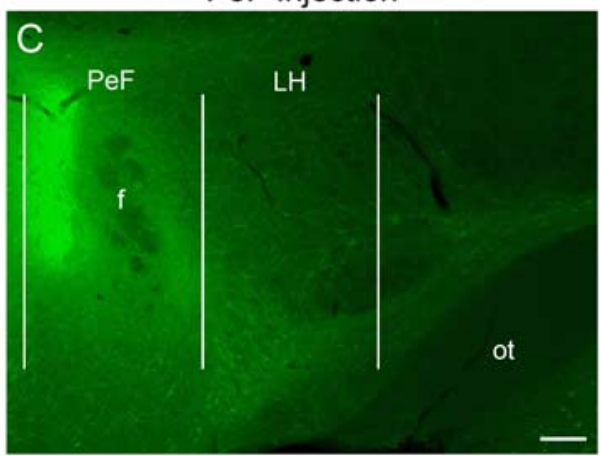

Nucleus Accumbens
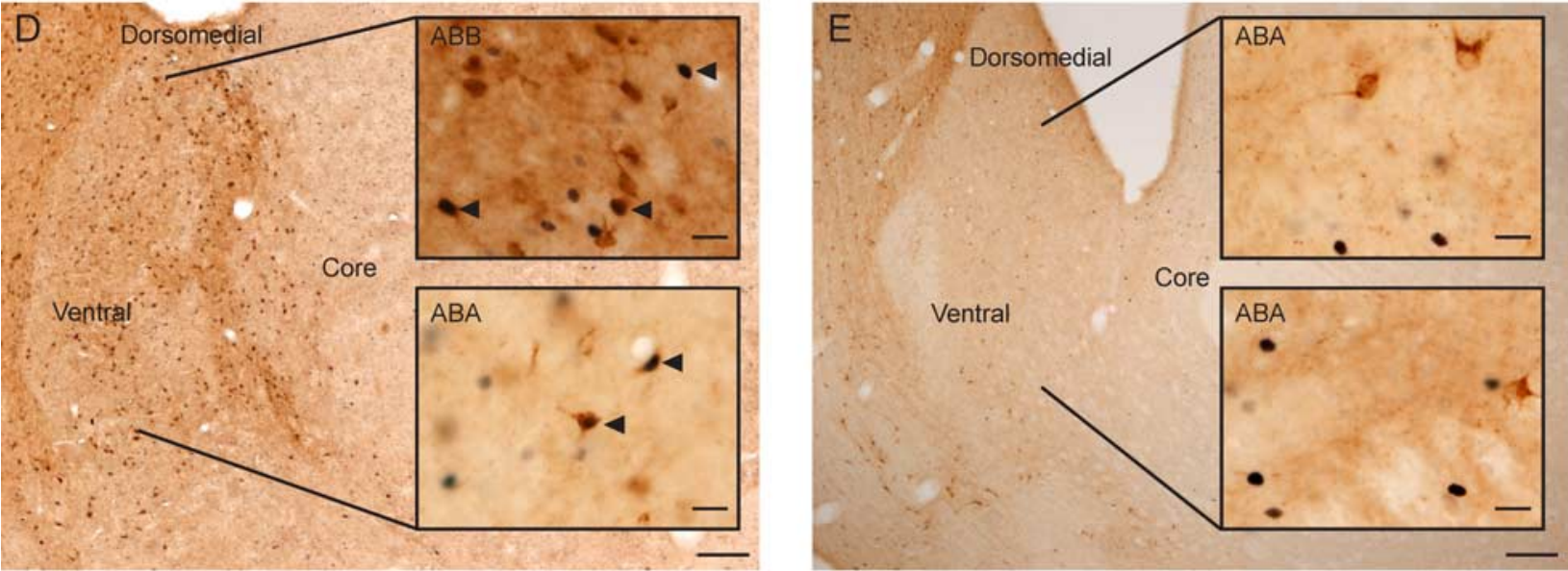

$\mathrm{F}$
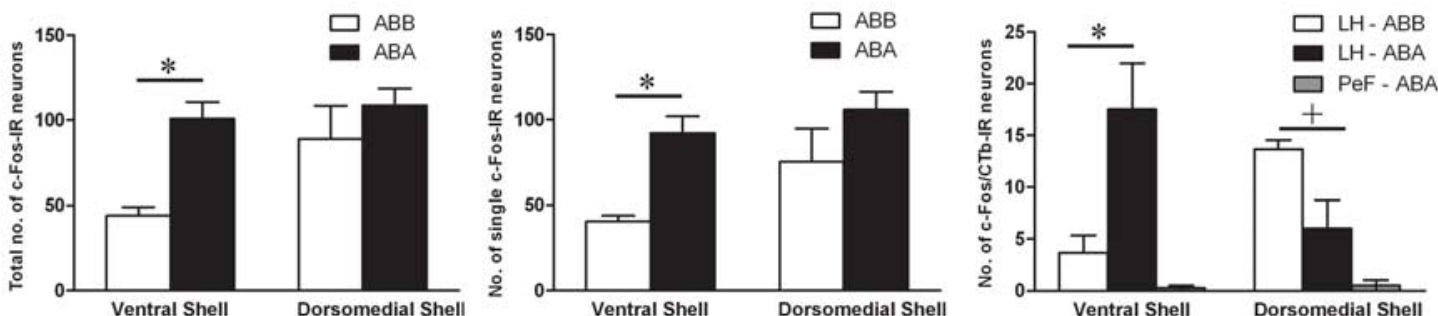

Figure 3. Activated afferents of $L H$ during renewal of alcoholic beer seeking. $A$, Mean ( \pm SEM) responses on the active (closed squares) and inactive (open squares) nose poke during extinction (left) and test (right). Rats were trained in context $A$, extinguished in context $B$, and then tested in either context $A$ (group ABA) or context $B$ (group ABB). Return to the original training context after extinction resulted in renewal. $\boldsymbol{B}, \boldsymbol{C}$, Fluorescent photomicrographs of representative injection sites of $40 \mathrm{~nL}$ of the retrograde tracer CTb in either the LH (B) or PeF (C). Scale bars, $200 \mu \mathrm{m}$. $\boldsymbol{D}, \boldsymbol{E}$, Photomicrographs of representative (Tb-IR in the nucleus accumbens after injections of CTb in either the $L H$ (D) or PeF (E). Scale bars, $200 \mu \mathrm{m}$. $\boldsymbol{D}$, Arrowheads point to c-Fos-IR/CTb-IR cells found in the dorsomedial shell in ABB rats (top inset) and c-Fos-IR/CTb-IR cells found in the ventral shell in ABA rats after LH CTb injection (bottom inset). $E$, Top and bottom insets show c-Fos-IR only and CTb-IR only cells in the dorsomedial (top) and ventral (bottom) shell found in ABA rats after PeF (Tb injection. Scale bars (for insets), $20 \mu \mathrm{m}$. $\boldsymbol{F}$, Effect of renewal of alcoholic beer seeking on c-Fos-IR in the dorsomedial and ventral shell. Bars show the mean ( \pm SEM) total number of c-Fos-IR cells (left), single labeled c-Fos-IR cells (middle), and c-Fos-IR/CTb-IR-labeled cells (right). A specific induction of c-Fos that was associated with ABA renewal was detected in the ventral shell. There was a specific induction of c-Fos in LH-projecting cells associated with ABA renewal in the ventral shell. In the dorsomedial shell there was a specific induction of c-Fos in LH-projecting cells in ABB rats. Induction of c-Fos in PeF-projecting cells was rare. ${ }^{*} p<0.05$ comparing total c-Fos cells in the ventral shell for $A B A$ with $A B B$ (left), non-CTb-IR c-Fos cells in the ventral shell for $A B A$ with $A B B$ (middle), and total double-labeled cells in the ventral shell for $A B A$ with $A B B\left(\right.$ (right); ${ }^{+} p<0.05$ comparing total double-labeled cells in the dorsomedial shell for ABA with ABB after CTb injection into LH (right). 

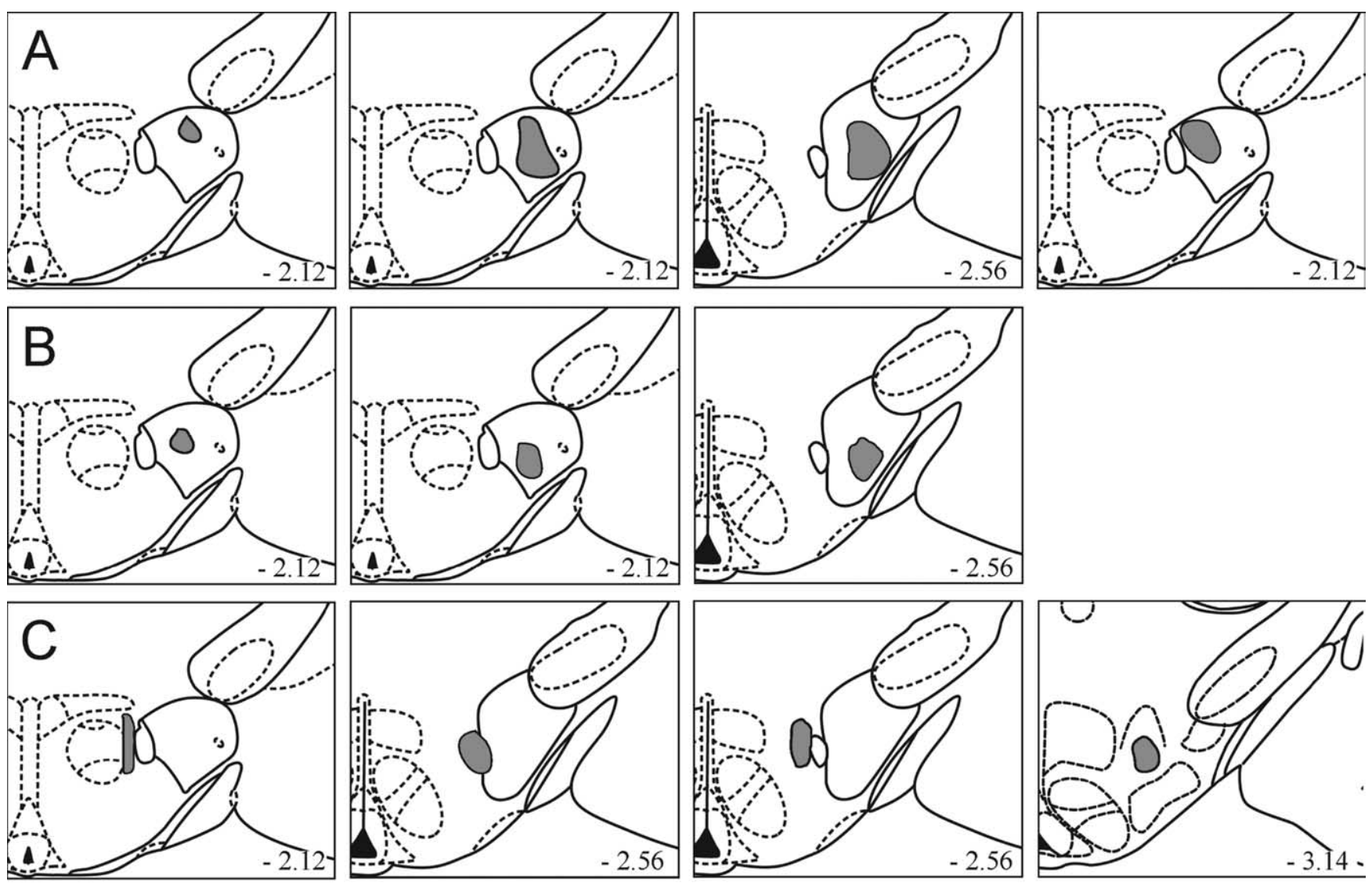

Figure 4. CTb injection sites for individual rats. $\boldsymbol{A}-\boldsymbol{C}$, The maximum extent of $(\mathrm{Tb}-\mathrm{IR}$ (enclosed gray area) in $L H(\boldsymbol{A}, \boldsymbol{B})$ or PeF $(\boldsymbol{C})$ is plotted for each rat on coronal sections based on the atlas of Paxinos and Watson (1997). Numbers indicate distance from Bregma in millimeters. $A$, Rats that received CTb injections into the $L H$ and were tested in the original training context (LH ABA). B, Rats that received (Tb injections into the $L H$ and tested in the extinction context ( $L H A B B$ ). C, Rats that received CTb injections into the PeF and tested in the original training context (PeF ABA).

about the neuroanatomical specificity of any double c-Fos/ CTb-IR observed in group ABA LH. Nonetheless, this finding suggests further research studying activated afferents to PeF during renewal may be worthwhile.

The statistical analyses described above were repeated for dual-IR based on percentage of c-Fos-IR neurons expressing $\mathrm{CTb}$-IR as well as for percentage of CTb-IR neurons expressing c-Fos-IR. These analyses revealed the same significant and nonsignificant differences between groups as described above for each brain region examined. The single exception was VTA. Analysis of VTA based on percentage of c-Fos-IR neurons expressing CTb-IR revealed a significant difference between groups $\mathrm{ABA}$ and $\mathrm{ABB}$ after $\mathrm{CTb}$ injection into $\mathrm{LH}\left(F_{(1,8)}=18.2 ; p<\right.$ 0.05 ) with significantly greater dual-labeling in group ABB. Likewise there was a significant difference in percentage of c-Fos-IR neurons expressing $\mathrm{CTb}-\mathrm{IR}$ after $\mathrm{CTb}$ injection into $\mathrm{LH}$ versus $\operatorname{PeF}\left(F_{(1,8)}=14.4 ; p<0.05\right)$.

\section{Discussion}

We used complementary functional and neuroanatomical approaches to study the role of LH in renewal of reward seeking. Extinction of reward seeking is context specific. Responding for either sucrose or an alcoholic beer reward was low when tested in the extinction context but was renewed when tested in the original training context. This highlights the important role for contexts in regulating reinstatement of drug seeking (Crombag and Shaham, 2002; Crombag et al., 2008). Renewal of both sucrose and beer seeking depended upon LH. Reversible inactivation of $\mathrm{LH}$ via $\mathrm{B} / \mathrm{M}$ infusions before test prevented renewal. This prevention was behaviorally specific because reversible LH inactivation had no effect on responding in the extinction context. Moreover, this prevention was neuroanatomically specific because unilateral $\mathrm{B} / \mathrm{M}$ infusion into $\mathrm{LH}$ or bilateral infusions of $\mathrm{B} / \mathrm{M}$ dorsal to LH had no effect on renewal. Together, these findings show that LH is required for renewal of extinguished reward seeking. Previous experiments have shown an increase in c-Fos expression in LH neurons during renewal of extinguished sucrose (Hamlin et al., 2006), alcoholic beer (Hamlin et al., 2007), and cocaine seeking (Hamlin et al., 2008). These experiments show a causal role for LH in renewal across two different reward types, adding to a growing body of evidence that LH is important for learning about and responding to reward associated stimuli (Harris et al., 2005, 2007).

We used dual-immunohistochemistry to identify activated afferents during renewal of beer seeking. CTb injection into $\mathrm{LH}$ produced a pattern of retrograde labeling similar to that reported previously (Petrovich et al., 2001, 2005; Yoshida et al., 2006) supporting the validity of the tracing approach. Of these afferents, differences in dual-IR for c-Fos and CTb were only observed for AcbSh, suggesting that AcbSh is a critical afferent to LH during renewal of beer seeking. The overall numbers of dual-labeled neurons in AcbSh were relatively low. However distinct neuronal ensembles in nucleus accumbens are associated with seeking or 
Table 2. Mean and SEM (in parentheses) number of Fos/CTb-IR dual-labeled, percentages of c-Fos-IR cells expressing CTb-IR (\% c-Fos), and percentages of CTb-IR cells expressing C-Fos-IR (\% CTb) after CTb injection into LH or PeF

\begin{tabular}{|c|c|c|c|c|c|c|c|c|c|}
\hline \multicolumn{4}{|c|}{ Count } & \multicolumn{3}{|c|}{$\%$ c-Fos } & \multicolumn{3}{|c|}{$\% \mathrm{CTb}$} \\
\hline & $\mathrm{LH}-\mathrm{ABA}(n=4)$ & $\mathrm{LH}-\mathrm{ABB}(n=3)$ & PeF-ABA $(n=4)$ & $\mathrm{LH}-\mathrm{ABA}(n=4)$ & $\mathrm{LH}-\mathrm{ABB}(n=3)$ & PeF-ABA $(n=4)$ & $\mathrm{LH}-\mathrm{ABA}(n=4)$ & $\mathrm{LH}-\mathrm{ABB}(n=3)$ & PeF-ABA $(n=4)$ \\
\hline AcbShDm & $6(2.7)$ & $13.7^{a}(0.8)$ & $0.5(0.5)$ & $6.5(3.1)$ & $16.6^{a}(2.8)$ & $0.4(0.4)$ & $3.0(1.2)$ & $6.4^{a}(0.3)$ & $0.5(0.5)$ \\
\hline AcbShV & $17.5^{b}(4.4)$ & 3.7 (1.4) & $0.25(0.3)$ & $17.3^{b}(3.7)$ & $7.7(3.3)$ & $0.3(0.3)$ & $4.8^{b}(0.8)$ & $1.7(0.7)$ & $0.3(0.3)$ \\
\hline $\mathrm{AcbC}$ & $4.3(2.4)$ & $2.7(0.8)$ & $0(0)$ & $6.4(4.5)$ & $2.8(1.0)$ & $0(0)$ & $1.7(0.9)$ & $2.7(1.3)$ & $0(0)$ \\
\hline plPFc & $11(5.3)$ & $7.7(4)$ & $15.3(5)$ & $4.4(1.9)$ & $4.3(1.8)$ & $6.8(2.1)$ & $5(2.2)$ & $5.2(1.7)$ & $7.4(2.6)$ \\
\hline ilPFC & $9.5(4.7)$ & $9.3(3.1)$ & $12.5(4.9)$ & $6.6(2.7)$ & $8.3(1.7)$ & $9(1.5)$ & $6.4(3.2)$ & $6.2(1.2)$ & $7.7(2.2)$ \\
\hline PvTa & $15.5(4)$ & $18.7(3)$ & $31.3^{c}(1.8)$ & $7.8(2.4)$ & $9.8(1.8)$ & $14.5^{c}(0.4)$ & $18.2(1.7)$ & $19.5(0.7)$ & $27.3^{c}(3)$ \\
\hline PvTm & $8.5(3)$ & $8(2.8)$ & $8.7(1.5)$ & $9.1(3.2)$ & $7.6(2.7)$ & $9.2(1.1)$ & $19.3(7.4)$ & $17.1(4.8)$ & $21.7(6.8)$ \\
\hline PvTp & $8.8(6.1)$ & $5.7(0.3)$ & $11.3(4.5)$ & $11.5(9.1)$ & $5.3(0.7)$ & $7.8(2.8)$ & $11.8(7.1)$ & $12.7(1.0)$ & $20.7(5.5)$ \\
\hline VTA & $7(4.1)$ & $13.3(3.5)$ & $6.3(1.5)$ & $15.6(3.6)$ & $35.3^{a}(3.7)$ & $11.1^{d}(1.2)$ & $8.5(3.7)$ & $18.1(6.3)$ & $10(2.5)$ \\
\hline DR & $12.3(6.5)$ & $8.3(1.3)$ & $17.3(8.1)$ & $12.6(4.9)$ & $14.5(1.3)$ & $14.8(6.0)$ & $6.8(3.6)$ & $4.7(0.7)$ & $13.3(5.8)$ \\
\hline LC & $3.8(1.9)$ & $3(0.5)$ & $4(2.4)$ & $20.0(8.8)$ & 35.7 (19.3) & $15.3(10.3)$ & $5.4(2.5)$ & $3.6(0.9)$ & $5.7(3.4)$ \\
\hline
\end{tabular}

${ }^{a} \mathrm{LH}-\mathrm{ABB}>\mathrm{LH}-\mathrm{ABA}, p<0.05 ;{ }^{b} \mathrm{LH}-\mathrm{ABA}>\mathrm{LH}-\mathrm{ABB}, p<0.05 ;$; PeF-ABA $>$ LH-ABA/ABB, $p<0.05 ;{ }^{d}$ PeF-ABA $<$ LH-ABA $/ \mathrm{ABB}, p<0.05$. PVTa, Anterior PVT; PVTm, middle PVT; PVTp, posterior PVT; DR, dorsal raphe; LC, locus coeruleus.

receipt of distinct rewards so that only a restricted population of LH-projecting neurons might have been able to be recruited under present conditions (Carelli and Wondolowski, 2003; Deadwyler et al., 2004; Roitman et al., 2005). The functional significance of an Acb-LH pathway in reinstatement of reward seeking remains to be verified but it has been established in other preparations (Kelley, 2004), and the present results suggest that this pathway is relevant to understanding reinstatement of reward seeking. Interactions between AcbSh and LH during contextinduced reinstatement were observed for two anatomically distinct groups of AcbSh neurons. First, there were significantly more activated $\mathrm{LH}$ projection neurons in AcbShV of group ABA showing that context-induced reinstatement is associated with recruitment of a direct AcbShV-LH pathway. This recruitment was specific to LH because it was not observed for PeF-projecting AcbShV neurons. It is unlikely that the greater dual-IR c-Fos/ $\mathrm{CTb}$ in AcbShV of LH ABA rats was a result of increased numbers of IR cells overall. Increased dual-IR c-Fos/CTb does not necessarily follow from the presence of c-Fos and CTb IR or differences between groups in IR. For example, there were significant differences between groups in dual-IR c-Fos/CTb in AcbShDm despite no differences in total c-Fos-IR or total CTb-IR. There were large numbers of single CTb-IR and single c-Fos-IR neurons in AcbC as well as infralimbic $\mathrm{PFc}$ (ilPFc) and prelimbic prefrontal cortex ( $\mathrm{plPFc}$ ) but no differences between groups in dual-IR c-Fos/CTb. Moreover, we have not detected dual-IR c-Fos/CTb in AcbSh (after CTb injection into LH) or in LH (after CTb injection into VTA) during renewal of cocaine seeking despite large numbers of single c-Fos-IR and CTb-IR neurons and differences between groups in single-IR c-Fos in these regions (Hamlin et al., 2008).

AcbSh is critical for renewal. AcbSh infusion of $\mathrm{D}_{1}$ dopamine receptor antagonists attenuates renewal of heroin seeking (Bossert et al., 2007), whereas B/M infusions attenuate renewal of cocaine seeking (Fuchs et al., 2008). AcbSh neurons respond to stimuli associated with drug-availability (Ghitza et al., 2003), and increased c-Fos in the AcbShV is associated with renewal (Hamlin et al., 2007). A $D_{1}$ dopamine receptor antagonist prevents the increased c-Fos expression in LH during renewal (Hamlin et al., 2006, 2007), consistent with a role for AcbSh in LH contributions to renewal. An AcbSh-LH pathway has been implicated in feeding (Kelley, 1999, 2004; Stratford and Kelley, 1999). For example, inhibition of AcbSh by GABA agonists increases feeding in sated rats in an LH-dependent manner (Stratford and Kelley, 1999). However, to the best of our knowledge, this is the first time that a direct AcbShV-LH pathway has been implicated in reinstatement of reward seeking. Renewal-associated c-Fos induction was also detected in single-labeled AcbShV neurons which did not project to LH. Whether these single-labeled neurons are interneurons, or whether they project to targets other than LH, remains to be determined.

The second interaction observed between AcbSh and LH during renewal was recruitment of a direct AcbShDm-LH pathway. There were significantly more activated LH projection neurons in AcbShDm of group ABB compared with group ABA. This finding shows that placement in the extinction context is associated with specific recruitment of an AcbShDm-LH pathway. This is interesting because extinction of reward seeking does not erase the original learning for reward seeking. Rather, extinction training acts specifically to inhibit reward seeking in the physical and temporal context in which extinction occurs (Bouton, 2002). In other words, the available evidence suggests that the low level of responding on test in the extinction context (group $\mathrm{ABB}$ ) is due specifically to an active inhibition of reward seeking. The finding that an AcbShDm-LH pathway was recruited following placement in the extinction context raises the possibility that this pathway may contribute to such inhibition. The absence of an effect of $\mathrm{B} / \mathrm{M}$ infusion in group $\mathrm{ABB}$ is not inconsistent with this possibility because such infusions might abolish both the mechanisms for inhibition and reinstatement of responding.

AcbShV was the only LH afferent with significant dual-IR c-Fos/CTb associated with renewal. Petrovich et al. (2005) showed upregulated immediate early genes in LH-projecting neurons in orbitomedial PFC, BLA, and basomedial amygdala after presentation of a stimulus paired with food. A large number of forebrain afferents to LH have been implicated in renewal of drug seeking, including BLA, dmPFC (Fuchs et al., 2005), and AcbSh (Bossert et al., 2007; Fuchs et al., 2008). Different afferents may converge on $\mathrm{LH}$ as a final common pathway for reinstating extinguished reward seeking. It will be of interest to determine whether LH contributes to other forms of reinstatement and to determine LH and AcbShV-LH pathway contributions to renewal of seeking other rewards. We have shown that LH neurons are recruited, as indexed by c-Fos, during renewal of seeking sucrose, alcoholic beer, and cocaine. However, we failed to detect recruitment of an AcbSh-LH pathway during renewal of cocaine seeking (Hamlin et al., 2008). This might imply that a AcbSh$\mathrm{V}-\mathrm{LH}$ pathway is important in renewal based on oral rewards and that other afferents are important for renewal based on intravenous rewards. This possibility requires further experimentation but it emphasizes the point that the circuit level mechanisms for renewal may depend on the nature of the reward.

It is worth considering whether orexin mediates LH contributions to renewal. Orexin neurons have received considerable attention regarding their role in motivated behavior (Harris et al., 
2005, 2007; Harris and Aston-Jones, 2006). LH orexin neurons are recruited during renewal of beer seeking in a $\mathrm{D}_{1}$-dopamine receptor dependent manner, with the extent of c-Fos/orexin dual labeling correlating positively with the magnitude of behavioral renewal (Hamlin et al., 2007). LH orexin neurons are also recruited during reinstatement of ethanol seeking produced by an olfactory discriminative stimulus (Dayas et al., 2008). Moreover, the orexin antagonist SB 334867 prevents cue induced reinstatement of ethanol seeking (Lawrence et al., 2006). It remains to be determined whether an orexin antagonist prevents contextinduced reinstatement. However, AcbSh projections to LH are largely segregated from orexin neurons (Sano and Yokoi, 2007). Moreover, LH orexin neurons are not recruited during renewal of sucrose seeking yet the present results show that LH is critical for such renewal. Together, these findings suggest LH contributions to renewal are likely to include nonorexin neurons and that if orexin is important for renewal then additional intra- $\mathrm{LH}$ pathways are likely to be important.

In conclusion, we have shown that LH is required for contextinduced reinstatement of reward seeking. Functional inactivation of LH before test prevented reinstatement of extinguished responding for both sucrose and alcoholic beer. The AcbSh was identified as an important LH afferent during renewal. AcbSh afferents could be classified into two groups. Context-induced reinstatement was associated with recruitment of an AcbShV LH pathway. Return to the extinction context was associated with low levels of responding and recruitment of an AcbShDm-LH pathway. These findings show that parallel striatal-hypothalamic pathways are recruited following return to the training versus extinction contexts.

\section{References}

Bossert JM, Liu SY, Lu L, Shaham Y (2004) A role of ventral tegmental area glutamate in contextual cue-induced relapse to heroin seeking. J Neurosci 24:10726-10730.

Bossert JM, Gray SM, Lu L, Shaham Y (2006) Activation of group II metabotropic glutamate receptors in the nucleus accumbens shell attenuates context induced relapse to heroin seeking. Neuropsychopharmacology 31:2197-2209.

Bossert JM, Poles GC, Wihbey KA, Koya E, Shaham Y (2007) Differential effects of blockade of dopamine D1-family receptors in nucleus accumbens core or shell on reinstatement of heroin seeking induced by contextual and discrete cues. J Neurosci 27:12655-12663.

Bouton ME (2002) Context, ambiguity, and unlearning: sources of relapse after behavioral extinction. Biological Psychiatry 15:976-986.

Bouton ME, Bolles RC (1979) Contextual control of the extinction of conditioned fear. Learning and Motivation 10:445-466.

Boutrel B, Kenny PJ, Specio SE, Martin-Fardon R, Markou A, Koob GF, de Lecea L (2005) Role for hypocretin in mediating stress-induced reinstatement of cocaine-seeking behavior. Proc Natl Acad Sci U S A 102:19168-19173.

Burattini C, Gill TM, Aicardi G, Janak PH (2006) The ethanol selfadministration context as a reinstatement cue: acute effects of naltrexone. Neuroscience 139:877-887.

Carelli RM, Wondolowski J (2003) Selective encoding of cocaine versus natural rewards by nucleus accumbens neurons is not related to chronic drug exposure. J Neurosci 23:11214-11223.

Crombag HS, Shaham Y (2002) Renewal of drug seeking by contextual cues after prolonged extinction in rats. Behav Neurosci 116:169-173.

Crombag HS, Grimm JW, Shaham Y (2002) Effect of dopamine receptor antagonists on renewal of cocaine seeking by reexposure to drugassociated contextual cues. Neuropsychopharmacology 27:1006-1015.

Crombag HS, Bossert JM, Koya E, Shaham Y (2008) Context induced relapse to drug seeking: a review. Philos Trans R Soc Lond B Biol Sci 363:3233-3243.

Dayas CV, McGranahan TM, Martin-Fardon R, Weiss F (2008) Stimuli linked to ethanol availability activate hypothalamic CART and orexin neurons in a reinstatement model of relapse. Biol Psychiatry 63:152-157.

Deadwyler SA, Hayashizaki S, Cheer J, Hampson RE (2004) Reward, memory and substance abuse: functional neuronal circuits in the nucleus accumbens. Neurosci Biobehav Rev 27:703-711.

Diergaarde L, de Vries W, Raasø H, Schoffelmeer AN, De Vries TJ (2008) Contextual renewal of nicotine seeking in rats and its suppression by the cannabinoid-1 receptor antagonist Rimonabant (SR141716A). Neuropharmacology 55:712-716.

Fuchs RA, Evans KA, Ledford CC, Parker MP, Case JM, Mehta RH, See RE (2005) The role of the dorsomedial prefrontal cortex, basolateral amygdala, and dorsal hippocampus in contextual reinstatement of cocaine seeking in rats. Neuropsychopharmacology 30:296-309.

Fuchs RA, Eaddy JL, Su ZI, Bell GH (2007) Interactions of the basolateral amygdala with the dorsal hippocampus and dorsomedial prefrontal cortex regulate drug context induced reinstatement of cocaine-seeking in rats. Eur J Neurosci 26:487-498.

Fuchs RA, Ramirez DR, Bell GH (2008) Nucleus accumbens shell and core involvement in drug context induced reinstatement of cocaine seeking in rats. Psychopharmacology 200:545-556.

Ghitza UE, Fabbricatore AT, Prokopenko V, Pawlak AP, West MO (2003) Persistent cue-evoked activity of accumbens neurons after prolonged abstinence from self-administered cocaine. J Neurosci 23:7239-7245.

Hamlin AS, Blatchford KE, McNally GP (2006) Renewal of an extinguished instrumental response: neural correlates and the role of D1 dopamine receptors. Neuroscience 143:25-38.

Hamlin AS, Newby J, McNally GP (2007) The neural correlates and role of D1 dopamine receptors in renewal of extinguished alcohol-seeking. Neuroscience 146:525-536.

Hamlin AS, Clemens KJ, McNally GP (2008) Renewal of extinguished cocaine-seeking. Neuroscience 151:659-670.

Harris GC, Aston-Jones G (2006) Arousal and reward: a dichotomy in orexin function. Trends Neurosci 29:571-577.

Harris GC, Wimmer M, Aston-Jones G (2005) A role for lateral hypothalamic orexin neurons in reward seeking. Nature 437:556-559.

Harris GC, Wimmer M, Randall-Thompson JF, Aston-Jones G (2007) Lateral hypothalamic orexin neurons are critically involved in learning to associate an environment with morphine reward. Behav Brain Res 183:43-51.

Harris, RJ (1994) ANOVA: an analysis of variance primer. Itasca, IL: F.E. Peacock.

Heimer L, Zahm DS, Churchill L, Kalivas PW, Wohltmann C (1991) Specificity in the projection patterns of accumbal core and shell in the rat. Neuroscience 41:89-125.

Hoebel BG (1979) Hypothalamic self-stimulation and stimulation escape in relation to feeding and mating. Fed Proc 38:2454-2461.

Kelley AE (1999) Neural integrative activities of nucleus accumbens subregions in relation to learning and motivation. Psychobiology $27: 198-213$.

Kelley AE (2004) Ventral striatal control of appetitive motivation: role in ingestive behavior and reward-related learning. Neurosci Biobehav Rev 27:765-776.

Kirouac GJ, Ganguly PK (1995) Topographical organization in the nucleus accumbens of afferents from the basolateral amygdala and efferents to the lateral hypothalamus. Neuroscience 67:625-630.

Lawrence AJ, Cowen MS, Yang HJ, Chen F, Oldfield B (2006) The orexin system regulates alcohol-seeking in rats. Br J Pharmacol 148:752-759.

Marinelli PW, Funk D, Juzytsch W, Li Z, Lê AD (2007) Effects of opioid receptor blockade on the renewal of alcohol seeking induced by context: relationship to c-fos mRNA expression. Eur J Neurosci 26:2815-2823.

O’Brien RG, Kaiser MK (1985) MANOVA approach for analyzing repeated measures designs: An extensive primer. Psychol Bull 97:316-333.

Paxinos G, Watson C (1997) The rat brain in stereotaxic coordinates, Ed 3. San Diego: Academic.

Petrovich GD, Canteras NS, Swanson LW (2001) Combinatorial amygdalar inputs to hippocampal domains and hypothalamic behavior systems. Brain Res Brain Res Rev 38:247-289.

Petrovich GD, Holland PC, Gallagher M (2005) Amygdalar and prefrontal pathways to the lateral hypothalamus are activated by a learned cue that stimulates eating. J Neurosci 25:8295-8302.

Richards JK, Simms JA, Steensland P, Taha SA, Borgland SL, Bonci A, Bartlett 
SE (2008) Inhibition of orexin-1/hypocretin-1 receptors inhibits yohimbine-induced reinstatement of ethanol and sucrose seeking in Long-Evans rats. Psychopharmacology 199:109-117.

Roitman MF, Wheeler RA, Carelli RM (2005) Nucleus accumbens neurons are innately tuned for rewarding and aversive taste stimuli, encode their predictors, and are linked to motor output. Neuron 45:587-597.

Sano H, Yokoi M (2007) Striatal medium spiny neurons terminate in a distinct region in the lateral hypothalamic area and do not directly innervate orexin/hypocretin- or melanin-concentrating hormone-containing neurons. J Neurosci 27:6948-6955.

Stratford TR, Kelley AE (1999) Evidence of a functional relationship between the nucleus accumbens shell and lateral hypothalamus subserving the control of feeding behavior. J Neurosci 19:11040-11048.
Usuda I, Tanaka K, Chiba T (1998) Efferent projections of the nucleus accumbens in the rat with special reference to subdivision of the nucleus: biotinylated dextran amine study. Brain Res 797:73-93.

Yoshida K, McCormack S, España RA, Crocker A, Scammell TE (2006) Afferents to the orexin neurons of the rat brain. J Comp Neurol 494:845-861.

Zahm DS, Brog JS (1992) On the significance of subterritories in the "accumbens" part of the rat ventral striatum. Neuroscience 50:751-767.

Zahm DS, Heimer L (1993) Specificity in the efferent projections of the nucleus accumbens in the rat: comparison of the rostral pole projection patterns with those of the core and shell. J Comp Neurol 327:220-232.

Zironi I, Burattini C, Aicardi G, Janak PH (2006) Context is a trigger for relapse to alcohol. Behav Brain Res 167:150-155. 